University of Nebraska - Lincoln

DigitalCommons@University of Nebraska - Lincoln

10-1956

\title{
Effects of Water Fluctuation and Vegetation Change on Bird Populations, Particularly Waterfowl
}

\author{
Paul A. Johnsgard \\ University of Nebraska-Lincoln, pajohnsgard@gmail.com
}

Follow this and additional works at: https://digitalcommons.unl.edu/johnsgard

Part of the Ornithology Commons

Johnsgard, Paul A., "Effects of Water Fluctuation and Vegetation Change on Bird Populations, Particularly Waterfowl" (1956). Paul Johnsgard Collection. 2.

https://digitalcommons.unl.edu/johnsgard/2

This Article is brought to you for free and open access by the Papers in the Biological Sciences at DigitalCommons@University of Nebraska - Lincoln. It has been accepted for inclusion in Paul Johnsgard Collection by an authorized administrator of DigitalCommons@University of Nebraska - Lincoln. 
Ecology, Vol. 37, No. 4 (Oct., 1956), pp. 689-701

October, 1956

WATER FLUCTUATION AND WATERFOWL

689

\section{EFFECTS OF WATER FLUCTUATION AND VEGETATION CHANGE ON BIRD POPULATIONS, PARTICULARLY WATERFOWL ${ }^{1}$}

Paul A. Johnsgard

Department of Zoology, Washington State College, Pullman, Washington

\section{INTRODUCTION}

In recent years reclamation activities in the Columbia Basin of Washington have resulted in profound changes in the character of the entire landscape throughout this region. The present study is an attempt to clarify some of the biological effects of impoundment behind O'Sullivan Dam in the Potholes area, Grant County (Johnsgard 1955b).

In this area, a large expanse of moving sand

${ }^{1}$ Contribution (No. 2) from the Washington Wildlife Research Project, the State of Washington Department of Game and the State College of Washington cooperating. dunes and a high water table are responsible for causing the formation of numerous small water areas, or "potholes," between the dunes. The physical nature of the area and its limited potentialities have made it of little value to man in the past, and it has only been subjected to grazing. Except for this influence the area remained almost undisturbed until the completion of O'Sullivan Dam and the formation of Potholes Reservoir. The reservoir has flooded many of the potholes and has materially raised the levels of those remaining. The objective of this study is an attempt to correlate these water level and vegetational changes with changes in avian populations, thus 
providing a means of predicting future population changes and population potential.

Ecologic work was begun in the area by Stanley W. Harris in 1950 (1952, 1954). His study provides an indication of biotic conditions before the impoundment caused a measurable effect on the wildlife of the area, and is concerned primarily with waterfowl. Breeding waterfowl of the area were also studied in 1952 by Allen J. Greene, U. S. Fish and Wildlife Service. From June 15 to August 15, 1953, and from February 15 to August 15, 1954, intensive field work for the present study was conducted in the area. Periodic surveys were also made during the fall and winter of 1953.

\section{History of the Area}

The Potholes area (Fig. 1) lies in the approximate center of the Columbia Basin of east-central Washington. It is located east of the Columbia River and north of Frenchman Hill, in a shallow depression known as the Quincy Basin.

Lava-flows covered the area, in some places to a depth of at least 4,000 feet, during the Miocene epoch. These flows were later subjected to gentle warping and folding, and were gradually covered with unconsolidated materials from a depth of a few to 250 feet (Bretz, 1928).

During the Pleistocene epoch the melting waters of the Wisconsin glacier spilled over eastern Washington, following the general slope of the land toward the southwest. The evidence of the magnitude of water volume involved and the velocity with which it raged across the landscape is vividly recorded in the present day scabland channels, dry cascades, mid-channel buttes, and other indications of a torrential water flow so great as to stagger the imagination.

The scouring action of this invading water cut through to bedrock on an area of over 2,800 square miles, and buried another 900 square miles in the glacial debris (Bretz 1928). These river channels, the "scablands," originate at four loci in the northern part of the basin. Portions of three of these scabland channels converge and empty into the Quincy Basin of Grant County. The sand that was deposited by these impounded glacial waters covers at least 24 townships and is the origin of the dunes which characterize the Potholes area.

Prevailing southwesterly winds have resulted in the formation of countless crescent-shaped dunes throughout the area. Many of the dunes have joined to form long ridges transverse to the prevailing winds, and range in height to 60 to 70 feet. In general, larger dunes occur where vegetation is almost absent, whereas the semistabilized dunes present a lower and more rounded aspect.

In the early 1900's many ranchers owned small desert claims and grazed herds of cattle throughout the region, especially during the relatively moist years of 1906-1916. At this time a local rancher, Budd McRenolds, estimated the number of potholes to be at least 2,500. Beginning about 1916 a series of dry years forced most of the settlers into bankruptcy; the desert claims were abandoned and many of the people put on relief. According to local residents the lowered water table caused many of the tule-lined potholes to dry up and be replaced with saltgrass flats (Budd McRenolds, personal communication).

In contrast to the estimated 2,500 potholes of the early 1900's, a count based on aerial photographs made in 1949 revealed 889 potholes. The filling of Potholes Reservoir has further reduced this number by flooding, so that the present number is estimated at 400 to 600 . Since new potholes resulting from a higher water table have not formed as rapidly as the old ones are being flooded, further reduction appears likely.

Construction of O'Sullivan Dam was begun in 1947 and was completed in 1951. The dam is earthfilled, rock-faced, about three and a half miles long, and has a maximum height of 207 feet above bedrock $(1,059$ feet above mean sea level). The impounded water will cover a maximum of about 30,000 acres and have almost 250 miles of shoreline. If raised to its proposed maximum elevation, 1,052 feet, it would coalesce with Moses Lake and raise its level about five feet. The reservoir is being raised approximately five feet per year, and maximum levels will likely be reached by 1958 . Maximum depths of 130 feet will occur near O'Sullivan Dam; maximum annual fluctuation will be about 19 feet. The purpose of the reservoir is to impound waste water from the northern part of the irrigation project for storage and re-use in the southern part. (The above data on the dam and reservoir were obtained mainly from the U.S. Fish and Wildlife Service and the State of Washington Department of Game, 1953).

\section{Climate and Vegetation}

Lying in the rain shadow of the Cascade Mountains, the Columbia Basin has a summer-dry climate and low total annual rainfall. Daubenmire (1942) concluded that "semidesert" is the most appropriate term for this region. Approximately two-thirds of the total precipitation falls during the six-month period October through March, reflecting the influence of an oceanic climate. A forty-year record of precipitation at Ephrata, 
Grant County, indicates an annual average of 7.9 inches (U. S. Dept. of Commerce, 1955), ranging from an average of 1.0 inch in January to 0.2 inch in July.

The area of study is located in the region designated as the Artemisia-Agropyron zone by Daubenmire (1942). The climatic climax is dominated by Artemisia tridentata Nutt. and one of the conspicuous grasses is Agropyron spicatum (Pursh) Scribn. \& Smith. Chrysothamnus nauseosus (Pall.) Britt. and C. viscidiflorus (Hook) Nutt. are present in sandy sites such as the Potholes area. In the area of intensive study Oryzopsis hymenoides (Roem. \& Schult) Ricker and Psoralea lanceolata Pursh dominate those parts of the dunes which are above the direct influence of the water table.

Proceeding southwesterly into the direction of the prevailing winds there is a gradual stabilization of the sand dunes, an increase in plant species present and a higher percentage of vegetational cover. Along this northeast to southwesterly gradient the following three areas were selected for study (see Fig. 1) :

Area I-This area of active sand dunes has little or no plant coverage. Potholes show little

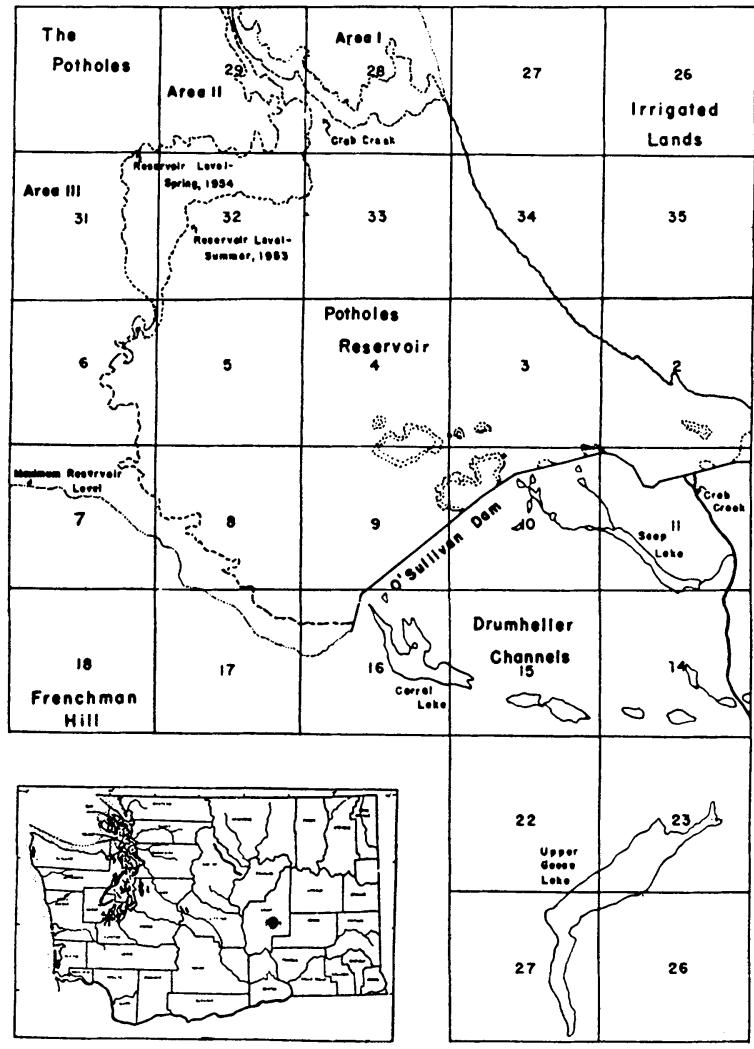

FIG. 1. Potholes Reservior and adjacent area, Grant County, Washington. indication of shoreline vegetation, and the few species present appear to be the first invaders in primary succession. A shrub zone is usually not present (Fig. 2b).

Area II-This is a transitional area having many active dunes, but most dunes are semistabilized. Potholes generally have a well-developed shoreline vegetation and emergent vegetation is fairly well developed. A shrub zone is normally present and well developed (Figs. 2a, 2c, 2d).

Area III-This is a semistablized area, having few active dunes and a relatively wide variety of both terrestrial and aquatic vegetation. Potholes have a well-developed shoreline and emergent vegetation, with the shrub zone often "capping" the dunes (Figs. 2e, 2f).

Under original conditions the potholes occurring in each of these areas were probably of uniform ecologic character, undergoing only minor yearly coincident water level fluctuations with the underground water table. Thus a distinctive stratification of plant life developed, as each species became established in that portion of the zonation pattern which placed it in its most favorable moisture relationship. Under these conditions perennial shrubs such as rabbitbrush, Chrysothamnus nauseosus and C. viscidiflorus, became an important part of the vegetational mosaic, forming, with Bromus tectorum L., an irregular zone about one to three feet above the permanent water level (referred to as the Bromus-Chrysothamnus zone). Below this zone, and bordering the pothole, a dense cover of salt-tolerant species, mainly saltgrass, Distichlis stricta (Torr.) Rydb., and sedge, Carex douglasii Boott. occurred (the Distichlis-Carex zone). Above the BromusChrysothamnus zone the more xeric environment allowed growth of only those species such as Psoralea lanceolata and Oryzopsis hymenoides (the Psoralea-Oryzopsis zone).

The original, undisturbed potholes supported dense stands of rushes, Juncus balticus Willd., bulrush, Scirpus acutus Muhl. and S. americanus Pers., and submerged aquatic vegetation. Harris (1954) has described in detail the typical aquatic vegetation of these potholes.

Willow trees, Salix spp., often occur near the potholes, but are not restricted to any part of the zonation pattern.

Underground seepage from the high water levels of Potholes Reservoir has disrupted this zontation scheme. Pothole water levels have become modified, the degree of change varying with their distance from the resorvoir. As a result of these 
changes several "types" of potholes have developed which, in order of decreasing modification, are defined as follows:

Type 0 -These are potholes which became temporarily inundated, and a part of Potholes Reservoir, during spring high-water levels. During the summer drawdown of the reservoir these potholes once again became separated from the reservoir. This pothole type was readily recognizable, not only by the occurrence of lake fish (Cyprinus carpio, Cottus asper and Ameiurus nebulosis) but also by the lack of shoreline and most emergent vegetation except Typha latifolia L. These potholes usually contained an abundance of dead, inundated rabbitbrush (Fig. 2a).

Type 1-These are potholes which are either newly formed, or if present previously all emergent and shoreline vegetation has been inundated. They are characterized by an abrupt transition from the water's edge to typical dune vegetation and lack all emergent aquatic vegetation. Newly formed potholes are easily recognized by the clarity of their water as opposed to the tea-colored water of older potholes (Fig. 2b).

Type 1a-These are potholes which are newly formed over depressions which had previously been covered with rabbitbrush (Chrysothamnus) and associated vegetation. They could be recognized by their shallowness, lack of aquatic vegetation and abundance of dead rabbitbrush standing in the water (Fig. 2c.)

Type 2-These potholes have been subjected to a rise in water level sufficient to flood most emergent vegetation, generally not great enough to inundate the entire shrub zone around the pothole. They are characterized by dead shrubs (mainly Chrysothamnus) along the shoreline, with few or no emergent aquatics (Fig. 2d).

Type 3-These potholes have not had a rise in water level sufficient to inundate the emergent vegetation or the shrub (Bromus-Chrysothamnus) zone, but enough to flood the lower shoreline vegetation (Distichlis-Carex zone). They are characterized by a few flooded shrubs and often show an inner area of emergent vegetation which marked the original size of the pothole (Fig. 2e).

Type 4-These potholes have not been noticeably affected by the reservoir, and have a stabilized and well-defined shoreline zonation with emergent vegetation extending to the shoreline. A Distichlis-Carex zone of shoreline vegetation is present (Fig. 2f).

Forty-seven ten-meter transects were staked out in the three areas and the vegetation analyzed during the second week of July, 1953. Each transect consisted of 20 contiguous 0.2 -meter by
0.5 -meter plots, from which coverage and frequency were determined. An approximate tenfoot rise in water levels of Potholes Reservoir during July and August of 1953 completely inundated all the vegetational transects established that year. In the spring and summer of 1954 the reservoir level was lowered and the transects were again exposed. Of the original 47 transects, stakes marking 25 escaped destruction. These transects, consisting of 500 plots, were again analyzed at the corresponding time to which they had been studied in 1953 .

On the basis of the changes found to occur during this interim, the following conclusions were made :

All species representative of the Psoralea-Oryzopsis zone appeared to be intolerant of prolonged submergence. Plants typical of this zone (Psoralea lanceolata, Oryzopsis hymenoides and Oenothera pallida Lindl.) which appeared in the 1954 transects were all seedlings; none represented those of the previous year.

In the Bromus-Chrysothamnus zone four species (Chry'sothamnus nauseosus, C. viscidiflorus, Bromus tectorum and Spartina gracilis Trin.) were completely removed from the vegetational matrix. Bromus tectorum reestablished itself in a prominant zone directly above the level marking maximum height of water levels, but the other three species were entirely eradicated. Annual forbs and grasses typical of the Bromus-Chrysothamnus zone (Lactuca scariola L., Hordeum jubatum L. and Corispermum hyssopifolium L.) reinvaded the transects, reaching their best development on previous Psoralea-Oryzopsis zone levels.

In the Distichlis-Carex zone changes were somewhat less extreme. Distichlis stricta survived submergence very well; in this zone it regained an abundance by July of about half its original coverage. Abundance in the higher zones was greater than before flooding; this resulted from rhizonatous growth and, to a lesser extent, seedling development. However, Carex douglasii was greatly reduced in abundance; seedling development appeared responsible for its presence in the 1954 transects. Annual grasses such as Polypogon monspeliensis (L.) Desf. and Panicum capillare $L$. were readily reestablished in the transects, although the perennial Muhlenbergia asperifolia (Nees. \& May) Parodi was apparently removed.

In addition to the decrease, increase, or locational changes of the original species, several species not typical of the Potholes vegetation were noted in the 1954 transects. These included Heliotropium curassivicum L., Chenopodium rubrum 


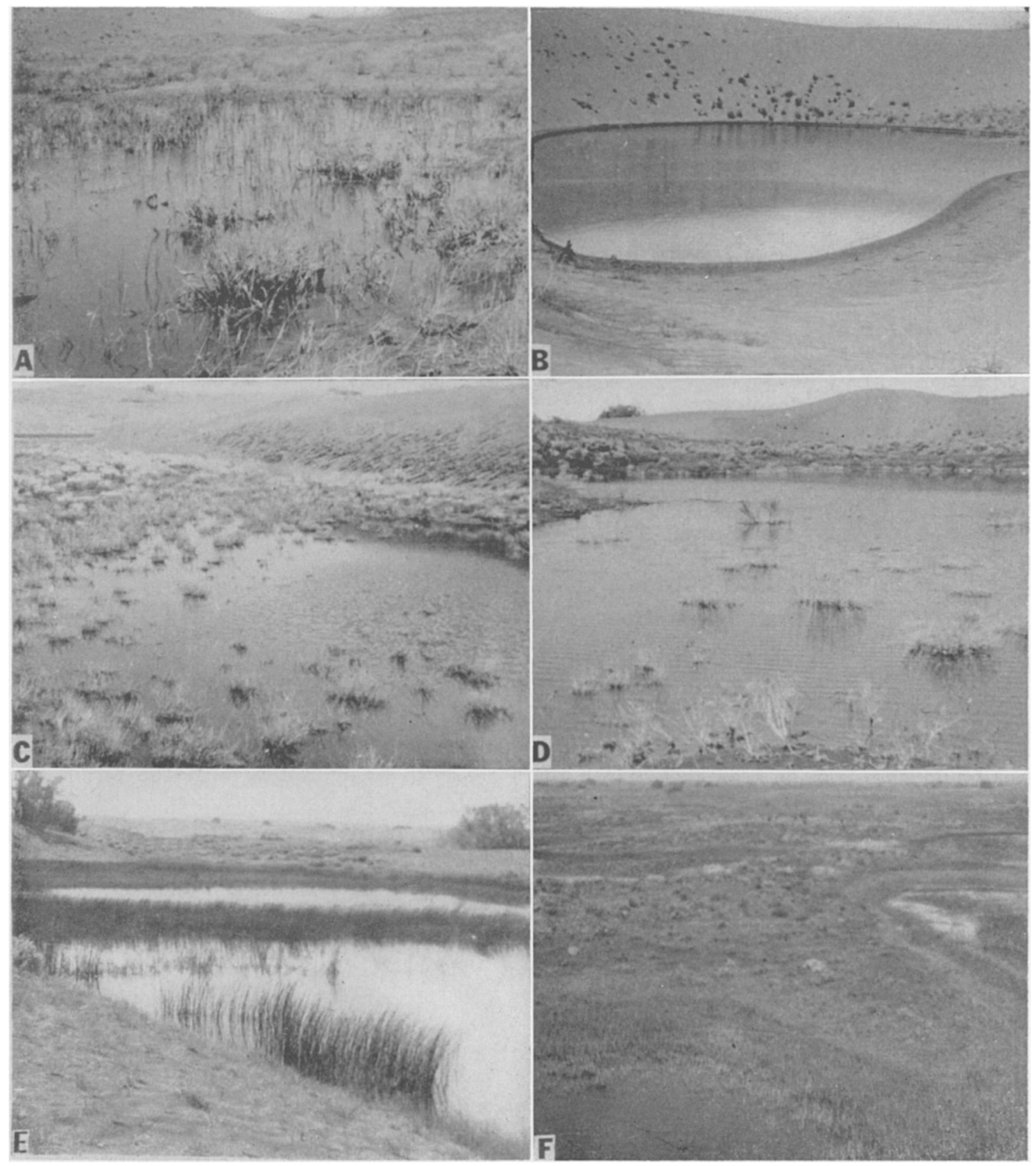

FIG. 2.

2a. Type O pothole, Area II. Note abundance of flooded Chrysothamnus. Typha latifolia is the only emergent species present.

2b. Type 1 pothole, Area I. Note lack of shoreline and emergent vegetation.

2c. Type la pothole, Area II. The numerous flooded shrubs are characteristic, as well as the lack of emergent aquatic vegetation. The lee slope of the adjajacent sand dune is covered with Rumex venosus, which is typical throughout the Potholes area.

2d. Type 2 pothole, Area II. This pothole type has an abundance of flooded Chrysothamnus, and usually some evidence of emergent Scirpus or Juncus vegetation.

2e. Type 3 pothole, Area III. Notice the stabilized character of the surrounding dunes. This pothole type has few or no flooded shrubs and a fair amount of emergent aquatic vegetation.

2.f. Type 4 notholes, Area III. Stable water levels and a well-defined shoreline zonation are typical characters of this pothole type. The lightest-colored zone is Distichlis-Carex; the Bromus-Chrysothamnus zone has covered the dune crests. 
L. and Xanthium strumarium L., all common irrigation weeds which no doubt entered Potholes Reservoir through the irrigation wasteways. Polygonum persicaria $\mathrm{L}$. was also observed in several locations. These and other species of weedy nature will doubtless increase in abundance as irrigation is intensified and the reservoir fluctuation becomes greater.

\section{Avian Distribution}

Sample potholes were selected for study and visited at regular intervals during the summer of 1953, and the spring and summer of 1954. Each route was surveyed from two to three times per week. During this survey all birds observed were recorded and assigned to the pothole on or about which they were seen. Terrestrial birds were assumed to be associated with the pothole nearest the vegetation in which the bird was seen. The small size and elusiveness of certain species during the breeding season precluded recording all birds present. However, it is believed that nearly all waterfowl and shorebirds were recorded, as well as most of the passerine and other species not directly associated with the potholes themselves.

Since sufficient typical examples of all pothole types did not occur in all areas, the most adequate bird distribution data for each area (indicated by Roman numerals) and pothole type (indicated by Arabic numerals) are presented (Figs. 3 and 4). Species showing similar distributional tendancies have been grouped together in these charts, and abundance has been calculated by dividing the number of observations per pothole type into the total number of individuals of a given species recorded for that particular area and pothole type. Data for Type 0 potholes are from Areas II and III combined; because this pothole type has such a distinctive history and extreme modification from the others it has been separated from them by a double line (Fig. 4). The lack of spring data for Type 4 potholes resulted from the high reservoir levels at that time, which greatly affected all pothole levels within distances. Lowered reservoir levels and an expanded route facilitated obtaining data for this pothole type during the summer. A discussion of each of the major species' ecologic status follows; additional information on relative bird abundance in the area has been published (Harris and Yocom 1952; Johnsgard 1954).

The pied-billed grebe (Podilymbus podiceps) is a common summer resident in the potholes; records were obtained for all areas and pothole types. The data suggest that its highest abundance is reached on pothole Types 3 and 4 , and it is probably more prevalent on the dense, over- grown Type 4 potholes than is apparent. Broods were observed on all but Type 1 potholes, indicating an unexpected adaptability to adverse nesting conditions.

The great blue heron (Ardea herodias) is a common permanent resident which nests in large numbers at Moses Lake. It was frequently observed along the shoreline of Potholes Reservoir but was uncommon in the potholes. It is most prevalent on Type 0 potholes (Fig. 4) which had recently become separated from Potholes Reservoir and still contained fish which had been stranded in the potholes as the reservoir receded.

The black-crowned night heron (Nycticorax nycticorax) is a common summer resident in the potholes and at Moses Lake, nesting on islands in the Columbia River. Distribution patterns are similar to those of the great blue heron; pothole Types $0,1 \mathrm{a}$ and 2 are heavily utilized. These pothole types, with their abundance of flooded shrubs, provide many excellent perches close to the food supply (mainly Rana pretiosa and Ambystoma tigrinum).

The Canada goose (Branta canadensis) is a common permanent resident, nesting on the islands of Potholes Reservoir and in the dune areas. A large part of this species' summer diet consists of Oryzopsis hymenoides seeds, the abundance of which is usually impoverished by cattle grazing. Geese often fed in the active dune area (Area I), where cattle rarely graze because of the relative scarcity of vegetation. The comparative seclusion from most other bird and mammalian disturbance may also partially account for their preference of this area.

The mallard (Anas platyrhynchos) is an abundant permanent resident in the area. During the spring (Fig. 3), including almost the entire nesting period, the distribution peak occurred on Type 3 potholes but extended over a broad ecologic range of pothole types. However, the summer data (Fig. 4) show a peak on the Type 2 and, to a lesser degree, Type $1 \mathrm{a}$ and 0 potholes. The reason is apparent; the flooded shrubs of the latter types provide an excellent shelter in which molting birds can skulk. Brood utilization was also highest for these potholes types. Besides the escape cover provided by the shrubs they seem to provide attraction for insects, and broods were often observed feeding about them.

The gadwall (Anas strepera), although never present in large numbers in the potholes, produced almost as many broods as did the ubiquitous mallard during 1953 and 1954. It slowly became evident that most gadwalls had territories along the shoreline of Potholes Reservoir; frequently their 

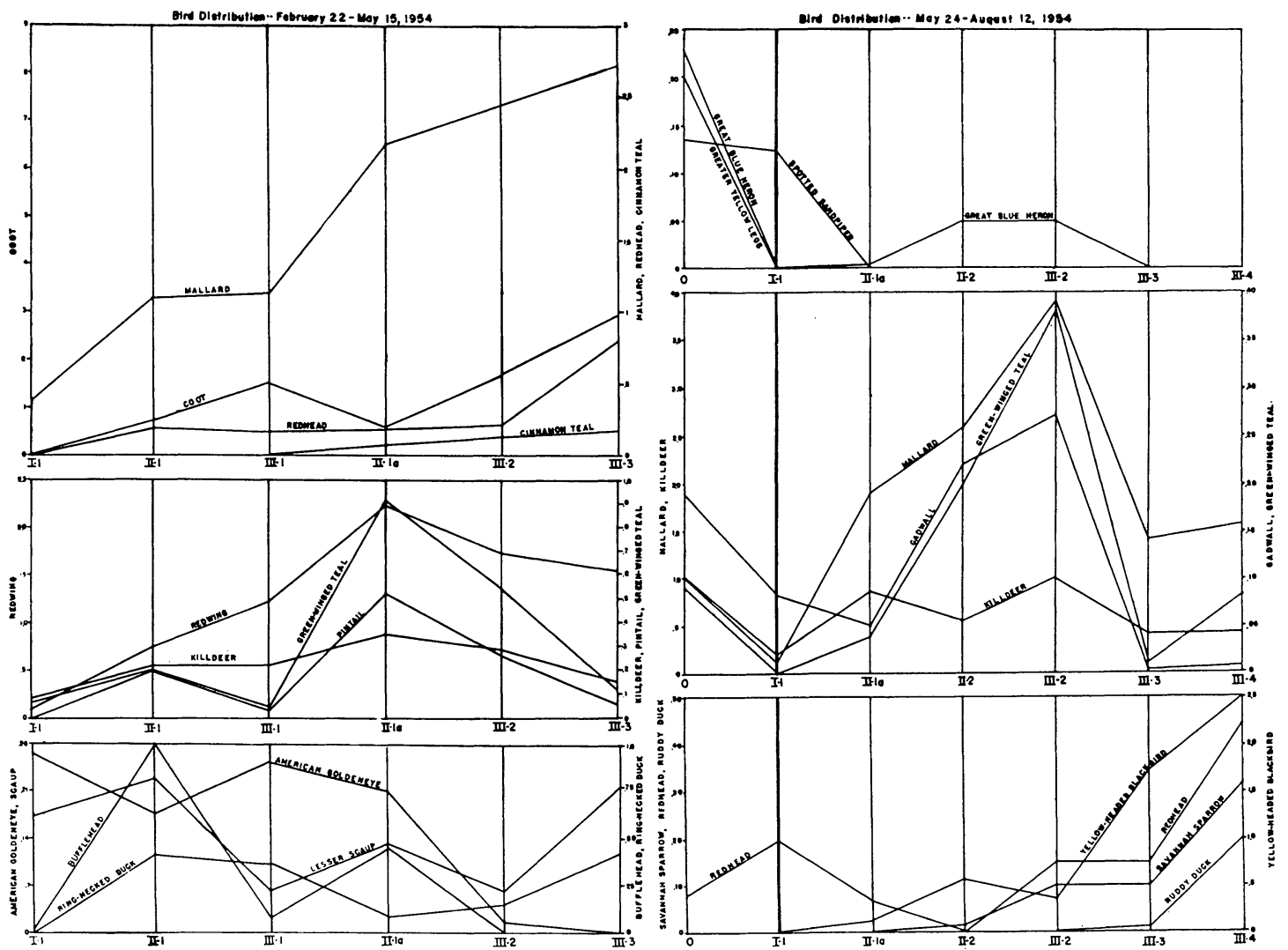

FIGS. 3 AND 4. Relative abundance of representative species on various areas (Roman numerals) and pothole types (Arabic numerals). Spring data (Fig. 3, left) based on 837 pothole observations, summer data (Fig. 4, right) based on 948 observations. Abundance equals total individuals recorded per areapothole type divided by the total number of observations for that area-type.

territories centered on dune islands and rarely did they include any potholes. Several investigators, including Bent (1923) and Miller and Collins (1954), have reported on the gadwall's proclivity for utilizing islands as nest sites. Thus the vast amount of potential habitat provided by the islands and shoreline of Potholes Reservoir helps account for the large brood production. The summer distribution data (Fig. 4) show that, of the potholes utilized, Types $0,1 \mathrm{a}$ and 2 are used almost exclusively; Types 3 and 4 are almost entirely avoided. This distribution also obtains for brood utilization. Nesting is usually far from water in the Psoralea-Oryzopsis zone.

The baldpate (Mareca americana) is an abundant migrant in the region, breeding in small numbers. The limited data suggest that its distributional preferences are rather similar to those of the gadwall.

The pintail (Anas acuta) is a common summer resident in the area, showing preferences for Type 2 potholes (Fig. 3 ). Its distribution pattern remained unchanged throughout the seasons ob- served, indicating no differences in nesting and postnesting preferences. Possible reasons for this distribution must be speculative; those advanced for the summer distribution of the mallard probably pertain.

The green-winged teal (Anas carolinensis) is a common summer resident in the area, with a distribution (Figs. 3 and 4 ) very similar to that of the pintail. Total brood production for the greenwinged teal and pintail dropped considerably in the Potholes area during 1954; both species prefer Type 2 potholes for nesting territories. Drawdown in reservoir levels during the nesting period resulted in most of the Type 2 potholes being transformed into stages resembling Types 3 or 4 , and most pintail and green-winged teal deserted their territories. Evidently the decrease in Type 2 potholes was closely correlated with the lower brood production of these two species.

The blue-winged teal (Anas discors) is an abundant summer resident in the Potholes area. Its distribution is very similar to that of the cinnamon teal (Fig. 3). Since the blue-winged teal 
is a late migrant spring distribution data are limited. However the summer data show greatest use of Type 3 potholes by adults and broods. Nesting preferences seem to be important in determining distribution; grasses of the DistichlisCarex zone, as well as Bromus tectorum, are preferred cover. Such cover is essentially lacking in all but pothole Types 3 and 4 . The preference of Type 3 over Type 4 potholes may result from the slightly higher water levels which probably influence food availability. Perhaps the greater percentage of open water also has territorial implications to this species.

As is the case with the mallard, there is a definite postnesting movement to Type 2 potholes where adult birds undergo molt. During this period it is impossible to distinguish blue-winged teal from cinnamon teal in the field, thus the two were treated together. Since these two species are relatively late nesters (early May to early August) a rise in water levels at this time might flood many of the nests, which are usually close to water.

The cinnamon teal (Anas cyanoptera) is a common summer resident in the Potholes area; its habits and distribution (Fig. 3) closely resemble those of the blue-winged teal. Pothole Types 3 and 4 are preferred by these species for nesting; Types 0,1 and $1 \mathrm{a}$ are avoided. Type 3 potholes were used most frequently by broods.

The shoveller (Spatula clypeata) is an uncommon summer resident in the area, and distribution data are limited. The data suggest a distribution peak on Type 2 potholes, although broods were recorded most often on Type 3 and 4 potholes.

The redhead (Aythya americana) is an uncommon summer resident in the area, and very few broods were recorded. Distribution data indicate a strong preference for pothole Types 3 and 4, particularly the latter (Figs. 3 and 4). Many females were observed to desert their nests and territories during 1954; this desertion was apparently the result of fluctuating water levels and the negligent behavior characteristic of the species. A few redheads were seen on Type 1 potholes during the summer, but these birds were very likely unsuccessful nesters, for no indications of territorialism were noted.

The ring-necked duck (Aythya collaris) is a common migrant in the area. Its spring distribution (Fig. 3) is similar to that of the lesser scaup, showing a bimodal curve with peaks on pothole Types 1 and 3 . In general, birds frequenting Type 1 potholes were unmated, whereas those on Type 3 potholes were mostly mated birds. Courtship activities among diving ducks generally occurred on deep and open water, as provided by the bays of Potholes Reservoir and the Type 1 potholes. Following mating, pairs usually moved to the more undisturbed potholes.

The lesser scaup (Aythya affinis) is a common migrant in the area. During spring most birds congregated on the larger lakes below O'Sullivan Dam, where courtship activities took place. Spring distribution in the potholes (Fig. 3) is similar to that of the ring-necked duck; possible explanations have been advanced in the discussion of that species.

The American goldeneye (Bucephala clangula) was observed in large numbers during the spring of 1954. The distribution patterns of the three species of Bucephala are unique and remarkably similar. A definite peak of abundance is found on Type 1 potholes; pothole Types 2 and 3 are almost entirely avoided by these species (Fig. 3). As with the other diving ducks, courtship usually occurred on Potholes Reservoir, lakes below O'Sullivan Dam, or on Type 1 potholes, presumably because of the large area of open water required for the frequent dives, chases, and other displays typical of these species (Johnsgard 1955a). However, in contrast to the ring-necked duck and lesser scaup, there is no utilization of Type 3 potholes. This appears to result from the fact that mated, nonmated and sexually immature goldeneyes and buffleheads tend to remain in groups. Such behavior made it practically impossible to determine the extent of mating, since all actively participated in courtship display.

Only a few records for the Barrow goldeneye (Bucephala islandica) were secured. However, in habits, courtship, and distribution it appeared very similar to the American goldeneye.

The bufflehead (Bucephala albeola) is a common migrant in the Potholes area, with habits and spring distribution that are closely similar to those of the American goldeneye. Its apparent intolerance of pothole Types 2 and 3 , and abundance of Types 1 and 1a (Fig. 3) was one of the most striking examples of habitat selection observed during the study.

The ruddy duck (Oxyura jamaicensis) is an uncommon summer resident in the Potholes area, restricted to the most remote and undisturbed Type 4 potholes (Fig. 4). During the spring of 1954 huge flocks congregated on Potholes Reservoir, but not until late May did pairs appear in the potholes. Broods were only observed on Type 4 potholes. As Low (1941) has pointed out, suitable nesting site is of particular importance to the ruddy duck's choice of breeding habitat. 
The sora (Porzana carolina) is a rare summer resident in the area, occurring mainly on Type 4 potholes. It is apparently somewhat less restricted in distribution than the Virginia rail (Rallus limicola), which was observed rarely on the most remote Type 4 potholes. However, it is believed that Type 4 potholes are necessary for the sora's nesting requirements, and that the few observations on other pothole types were not of territorial birds.

The coot (Fulica americana) is an abundant breeding resident in the Potholes area. During the spring of 1954 (Fig. 3) the greatest concentrations of migrating birds were found on Type 3 potholes, but distribution peaks occurred on Type 2 potholes during the summer. The reason for this behavior is readily apparent; Type 3 potholes provided the greatest abundance of food for migrants, but the inundated shrubs of Type 2 potholes provided a sturdy and convenient support for nests. Such shrubs might substitute for the emergent vegetation lost to rising water levels, but the inability of the bird to easily adjust the level of the nest to fluctuating water makes this choice of nest substrate a dangerous one. The relatively short nesting period (early May to early July) increases the probability of a high nest mortality during a rapid reservoir rise at this time. Brood utilization was high on pothole Types 2, 3 and 4 .

The killdeer (Charadrius vociferus), an abundant resident, was prevalent on Type 2 potholes during the spring and summer (Figs. 3 and 4 ). Lowered reservoir levels during the summer of 1954 caused the formation of numerous Type 0 potholes; killdeers and greater yellow-legs ( $T o-$ tanus melanoleucus) utilized these heavily (Fig. 4). Linsdale (1938) noted that the killdeer was associated with habitats that offered both freedom of movement and visibility; most shorebirds observed in the Potholes area exhibited this same behavior. Nesting extends from May to August, thus there is little danger of drastic population reduction caused by flooding.

The spotted sandpiper (Actitus macularia) is a common summer resident in the area. It was observed most often about pothole Types 0 and 1 (Fig. 4). A somewhat similar distribution was shown by the avocet (Recurvirostra americana), which breeds about Type 1 potholes. Territorial requirements of visibility and unhindered movement may account for its restricted distribution; it was encountered only about this pothole type.

The Wilson phalarope (Staganopus tricolor) is a common summer resident in the area and, like most shorebirds, was most abundant on Type 2 potholes. In contrast to other shorebirds how- ever, it was also prevalent on pothole Types 3 and 4. Its preference for grassy nest cover probably partially accounts for this distribution.

The black tern (Chlidonias niger), a common summer resident in the area, is restricted almost entirely to Type 4 potholes, where it nests on mats of floating bulrushes (Scirpus acutus and $S$. americanus). Other pothole types are apparently unsuited to the species' breeding requirements, and the birds rarely even feed about them.

The mourning dove (Zenaidura macroura) is a common summer resident in the area, usually nesting in willows adjacent to, or standing in, the water. Highest populations occurred about Type 4 potholes. The distribution appeared to be determined by available nesting trees rather than the pothole type.

The eastern kingbird (Tyrannus tyrannus) is an abundant summer resident in the area, and was most often seen about pothole Types 2, 3 and 4 . As with the mourning dove, the presence of willow for suitable nesting sites seems to determine distribution. Willows standing in water are especially preferred.

The western meadowlark (Sturnella neglecta), a common resident, has a distribution that appears to be more closely correlated with the area than the pothole type. The species was rare in the active dune area (Area I) but abundant in the semistabilized area (Area III). The bird's abundance appeared unaffected by water level changes, which probably reflects its upland affinities.

The yellow-headed blackbird (Xanthocephalus xanthocephalus) is a common summer resident in the area, occurring only in appreciable numbers on Type 4 potholes (Fig. 4). Undoubtedly dense stands of Scirpus acutus delineated the nesting distribution of this species in the Potholes area.

The redwing (Agelaius phoeniceus) is an abundant summer resident, being most abundant on pothole Types 1a, 2 and 4 (Fig. 4). On pothole Types $1 \mathrm{a}$ and 2 it nests on shrubs; on Type 4 potholes it nests in Scirpus, preferring the former. Paralleling the coot it thus modifies its nesting habits to allow for loss of emergent nesting cover. Most nests are placed close to water, the average height of 24 constructed in flooded Chrysothamnus averaged slightly over one foot above water. Thus a slight reservoir rise during the nesting season (mid-May to mid-June) would likely destroy a large pecentage of the nests.

The Brewer blackbird (Euphagus cyanocephalus) is uncommon during the nesting season, but large flocks pass through the area during 
July and August. The distribution of these wandering flocks is erratic, but often large numbers are seen feeding about pothole Types 1 and $1 \mathrm{a}$.

The Savannah sparrow (Passerculus sandwichensis) is an uncommon summer resident in the area. Its distribution (Fig. 4) is restricted, and appears to be closely associated with the Distichlis-Carex zone of Type 4 potholes. Dumas (1950) found it associated with marsh and prairie in southeastern Washington, and Booth (1952) related it to the "Palouse prairie association," both further indicating its affinity for grassy habitats. Where the Distichlis-Carex zone was not present in the Potholes area, this sparrow could not be found.

The vesper sparrow (Pooecetes gramineus), a common summer resident, is the most widely distributed sparrow in the Potholes area. It is the only species of sparrow seen frequently in the active dune area (Area I). Its wide occurrence seems attributable to its habit of nesting on the sand, and thus not being dependent on any particular nesting cover. Wing (1949) noted that the vesper sparrow was the only nesting species in the shrub-deficient Agropyron-Poa association of virgin Palouse prairie. Of 13 nests examined in the Potholes area, eight were beneath cover characteristic of the Psoralea-Oryzopsis zone and five were beneath Bromus-Chrysothamnus zone vegetation. This upland location, and the length of the nesting season (mid-May to early August) provides safety from population reductions through flooding.

The Brewer sparrow (Spizella breweri) is a common summer resident in the Potholes area, observed most frequently about pothole Types 1a and 2. The species is very closely associated with the presence of Chrysothamnus; all nests observed were built in rabbitbrush, and it was also a favorite perching site. The sparrow's abundance will almost certainly decrease at the same rate as Chrysothamnus in the Potholes area. Kennedy (1914) noted that this species disappeared quickly when sagebrush in the Yakima Valley was cleared for irrigation. Dumas (1950) found the Brewer sparrow associated only with "sagebrush" habitat (Artemisia spp. and Chrysothamnus spp.) in southeastern Washington. Booth (1952) correlated its occurrence in the Blue Mountains with the "sagebrush association," and considered suitable nest site as the probable limiting factor in its distribution.

An interesting apparent ecologic equivalent of the Brewer sparrow in the nearby Artemisia-dominated loamy uplands is the lark sparrow (Chon- destes grammacus). Although it was recorded only three times in the sand dune area during the eight months of field work, a fifteen-minute walk through a sagebrush area a few hundred yards away was certain to reveal several of these birds. Attempts to determine the causes for this distribution were unsuccessful, but apparently the physical characteristics of the sand dune vegetation were unsuited to the territorial requirements of the lark sparrow.

In summary, most of the birds studied in the dune environment showed a definite association with a particular pothole type or successional vegetation stage. In some cases this association appeared relatively simple and could be interpreted readily; in others the association was more complex and difficult to interpret. No two species were observed to have exactly the same habitat requirements, which often centered on a single factor such as suitable nest substrate, or several interrelated factors such as food availability, protective cover and territorial requirements. Regardless of the simplicity or complexity of these factors, the environmental changes caused by fluctuating water levels resulted in a redistribution of bird populations throughout the affected potholes. The obvious conclusion is that every bird species becomes part of the biotic community at a particular stage of plant succession and remains a part of that community until the successional stage transcends (or retrogresses below) the tolerance limits of the species.

\section{Waterfowl Populations}

Yearly brood production provides the best index of the effects of Potholes Reservoir on breeding waterfowl in the area. This is best illustrated by comparing data from potholes of similar sizes, which is presented (Table I) for the five-year period 1950-1954. Although the larger-sized potholes have been inundated, greatly reducing total production, production per pothole on the remaining smaller ones has increased considerably. This accelerated production probably means that breeding birds were forced into the smaller potholes as the larger ones became flooded. It is very unlikely, however, that this increase in nesting density plus additional nesting along the shoreline of Potholes Reservoir will ever attain the production potential previous to impoundment. In both 1953 and 1954 the annual reservoir rise was abnormally late, thus preventing direct loss by flooding. Seasonal occurrence and rate of reservoir rise will unquestionably have a tremendous influence on future waterfowl production in the area. In 
Ecology, Vol. 37, No. 4 (Oct., 1956), pp. 689-701

TABLE I. Waterfowl brood production, by size of pothole

\begin{tabular}{|c|c|c|c|c|c|c|c|c|}
\hline \multirow[t]{2}{*}{ Si: e of Pothole........ } & \multicolumn{2}{|c|}{1 Acre or Less } & \multicolumn{2}{|c|}{$2-4$ ACRES } & \multicolumn{2}{|c|}{$5-10$ ACRES } & \multicolumn{2}{|c|}{ More than 10 ACRES } \\
\hline & $\begin{array}{l}\text { No. of } \\
\text { broods }\end{array}$ & $\begin{array}{l}\text { No. of } \\
\text { potholes }\end{array}$ & $\begin{array}{l}\text { No. of } \\
\text { broods }\end{array}$ & $\begin{array}{l}\text { No. of } \\
\text { potholes }\end{array}$ & $\begin{array}{l}\text { No. of } \\
\text { broods }\end{array}$ & $\begin{array}{l}\text { No. of } \\
\text { potholes }\end{array}$ & $\begin{array}{l}\text { No. of } \\
\text { broods }\end{array}$ & $\begin{array}{l}\text { No. of } \\
\text { potholes }\end{array}$ \\
\hline $1950^{*} \ldots \ldots \ldots \ldots$ & 83 & 173 & 35 & 24 & 2 & 2 & 13 & 3 \\
\hline Broods per pothole, $1950 \ldots \ldots$. & \multicolumn{2}{|r|}{.48} & \multicolumn{2}{|c|}{1.5} & \multicolumn{2}{|c|}{1.0} & \multicolumn{2}{|c|}{4.3} \\
\hline $1951^{*} \ldots \ldots \ldots \ldots$ & 134 & 181 & 54 & 7 & 42 & 3 & 22 & 2 \\
\hline Broods per pothole, $1951 \ldots$ & \multicolumn{2}{|r|}{.75} & \multicolumn{2}{|c|}{9.0} & \multicolumn{2}{|c|}{14.0} & \multicolumn{2}{|c|}{11.0} \\
\hline $1952 \nmid \ldots \ldots \ldots \ldots$ & 135 & 190 & 35 & 16 & 28 & 3 & - & - \\
\hline Broods per pothole, $1952 \ldots$ & \multicolumn{2}{|r|}{.71} & \multicolumn{2}{|c|}{2.2} & \multicolumn{2}{|c|}{7.7} & \multicolumn{2}{|c|}{ - } \\
\hline 1953. & 108 & 91 & - & - & - & - & - & - \\
\hline Broods per pothole, $1953 \ldots$ & \multicolumn{2}{|c|}{1.2} & \multicolumn{2}{|c|}{-} & \multicolumn{2}{|c|}{ - } & \multicolumn{2}{|c|}{ - } \\
\hline $1954 \ldots \ldots \ldots \ldots$ & 114 & 97 & - & - & - & - & - & - \\
\hline Broods per pothole, 1954 & \multicolumn{2}{|c|}{1.2} & \multicolumn{2}{|c|}{-} & \multicolumn{2}{|c|}{-} & \multicolumn{2}{|c|}{-} \\
\hline
\end{tabular}

*Data from S. W. Harris (personal communication).

†Data from A. J. Greene (personal communciation).

normal years the reservoir rise will begin in midMay and continue through July.

Plants characteristic of the Distichlis-Carex zone provided cover for six percent of the total forty-nine terrestrial waterfowl nests located, the Bromus-Chrysothamnus zone provided 71 percent, and the Psoralea-Oryzopsis zone accounted for 21 percent. Salix, which is not associated with any single zone, contributed the remaining two percent. The importance of the Bromus-Chrysothamnus zone is thus apparent; Chrysothamnus alone provided cover for 50 percent of all the nests found. Since Chrysothamnus is highly vulnerable to permanent destruction by flooding, the possibility of desirable nesting cover becoming a limiting factor in future waterfowl production will be continually increasing.

A comparison of the fall migration of 1953 with that observed during 1951 (Harris 1952) is illuminating. Based on five counts over the area during fall migration, Harris found a total of almost 16,000 waterfowl, whereas about 19,000 were observed in similar counts during the present study. Apparently there is little significance between the total numbers of waterfowl counted and/or estimated to be present during each of the two years.

Far more significant is the great change in species composition observed during the two years. A tremendous increase in mallards, from 29.5 percent of all waterfowl observed in 1951 to 63.3 percent in 1953, is believed to reflect its fieldfeeding habits. Since it is not dependent on native vegetation for food, the inundation of the original potholes has not had any noticeable undesirable effects on its migratory status. About 85 percent of the food consumed by 37 mallards examined was composed of cultivated crops (corn, Zea mays, peas, Pisum sativum, and wheat, Triticum aestivum), whereas Harris (1952) found that 39 percent of the food of 21 mallards was from this source. Accordingly, species such as the diving ducks, which are not field feeders, suffered from the lack of native food and used the reservoir mainly as a safe resting place during hunting season.

Between 2,000 and 4,000 waterfowl, about twothirds of which were mallards, were present in the area during the winter of 1953-1954. This comprised approximately ten percent of the total waterfowl present in the Columbia Basin that winter. With the increasing size of Potholes Reservoir it appears that the wintering grounds provided by it will be one of the most important wildlife values of the area in future years. Data from Harris (1952) indicate that few birds wintered in the area previous to impoundment.

In addition to its wintering value, non-game species not recorded previous to impoundment often utilized the reservoir during the spring and summer. Among these were the double-crested cormorant (Phalacrocorax auritus) and herring gull (Larus argentatus). Western grebes (Aechmophorus occidentalis) and white pelicans (Pelecanus erythrorhynchos) were also common summer residents on the reservoir. 
Ring-billed gulls (Larus delaziarensis) rapidly colonized the newly formed dune islands of Potholes Reservoir following impoundment, nesting on the sand near the water's edge. During both years of study the reservoir level receded during the nesting season, thus nesting success was high. Since most nests are placed near the water a moderate rise in reservoir level during this time would destroy most of the colony.

Shorebirds of many species congregate along the beaches and islands of the reservoir during migration. Waterfowl, particularly Canada geese, mallards, gadwalls and coots, use the reservoir during the molting period. Numerous colonies of bank swallows (Riparia riparia) nest along the sand banks of Potholes Reservoir.

\section{Discussion}

Through a synthesis of the data obtained on vegetational changes and their relation to bird distribution and abundance, the following estimate of future bird populations of the Potholes area is possible:

(1) Subject to population reduction through direct nest flooding-Coot, redwing, redhead.

(2) Subject to population reduction through loss of breeding habitat-Blue-winged teal, cinnamon teal, ruddy duck, redhead, Virginia rail, sora, black tern, yellow-headed blackbird, Savannah sparrow.

(3) Subject to population reduction through loss of nesting cover-Brewer sparrow, coot, piedbilled grebe, pintail( ?), green-winged teal(?)

(4) Slightly affected by reservoir fluctuationGadwall, vesper sparrow, meadowlark, eastern kingbird.

These changes will be effected in several years, when reservoir fluctuations reach their maximum. The rate of population reduction will depend largely on the time of annual reservoir rise; rises occurring during several successive nesting seasons would hasten reduction greatly. Wolf (1955) found that total water level rise during the nesting season was not so important as rise per unit of time.

Species such as the sora, Virginia rail and ruddy duck, which are particularly adapted to and dependent upon undisturbed (Type 4) potholes, will be the first to show the effects of increased fluctuations. As Brock (1914) stated, "A species will show power of adaptation to new conditions in inverse ratio to the perfection of its adjustment to the old. ..." Similarly, blue-winged teal and cinnamon teal will respond later to the loss of Type 3 potholes. Since Type 2 potholes will be present for several years, pintail and green-winged teal should be present in fair numbers indefinitely. Mallards and gadwalls likewise will adapt themselves to the altered environmental relations very well.

One of the most impressive phenomena observed in the Potholes area was the resilence of most wildlife and vegetation to new conditions caused by flooding. Nevertheless, the net result of all the ecologic changes resulting from water fluctuation will be a decrease in the variety of fauna and flora, with a concurrent population increase of the few very adaptable species. Management under current conditions cannot hope to restore the variety of the original biota.

\section{ACKNOWLEDGMENTS}

I am deeply grateful to Dr. Irven O. Buss, Dr. Rexford F. Daubenmire, and Dr. George E. Hudson, all of whom provided many helpful criticisms and devoted much time to my problem. I am indebted to the State of Washington Department of Game and to the State College of Washington for the use of equipment during the field work, and for financial assistance during the entire period of study. I particularly wish to express my gratitude to Dr. Irven O. Buss for his careful reading and editing of my reports and manuscripts.

\section{Summary}

Research in the Potholes area of Grant County, Washington, was conducted during 1953-1954 with the primary objective of determining the biotic effects of water fluctuation. O'Sullivan Dam was constructed during 1947-1951; the resulting reservoir has flooded many of the original sand dune potholes and the water levels of those remaining have been materially affected.

Studies were made in three locations, which included an active dune area, a transitional area and a semistablized area. The potholes in each area were classified into six types as to degree of water level change caused by the reservoir, and ranging from Type $\mathrm{O}$ (potholes subjected to actual flooding by Potholes Reservoir) to Type 4 (potholes not noticeably affected, exhibiting a stable water level and undisturbed vegetation zonation).

Most bird species displayed a definite association with a particular pothole type or successional vegetation stage. This association could usually be attributed to the presence of suitable nest substrate, protective cover, food availability, territorial requirements, or combinations of these. The environmental changes caused by fluctuating water levels resulted in a redistribution of bird populations throughout the affected area. It was em- 
phasized that any bird species remains a part of the biotic community only so long as the successional vegetation stage encompasses the maximum tolerance limits of the species.

Flooding of the larger potholes has greatly reduced total waterfowl production and has forced the breeding waterfowl into the remaining smaller potholes. These smaller potholes have become more productive in recent years, which is probably a result of this movement. Rabbitbrush (Chrysothamnus nauseosus and $C$. viscidiflorus) is the most important terrestrial nesting cover for waterfowl in the Potholes area, but is being greatly reduced in abundance through flooding.

Potholes Reservoir has apparently not yet attracted significantly greater numbers of waterfowl to the area during fall migration, although fieldfeeding species such as mallards are much more abundant than previously. Three-square (Scirpus americanus) and saltgrass (Distichlis stricta) were found to be important native foods for waterfowl ; peas, corn and wheat comprised over threefourths of the food consumed by all mallards examined.

Attempts to preserve the original wildlife and vegetation of the area would be futile under present conditions of water fluctuation. Those species which are particularly adapted to conditions found in the most advanced vegetational stages have already been seriously affected and will be the first to be extirpated from the area. Only the most adaptable species will be able to persist.

\section{REFERENCES}

Bent, A. C. 1923. Life histories of North American wild fowl, Order Anseres (Part 1). U. S. Nat. Mus. Bull. 126: 1-250.

Booth, E. S. 1952. Ecological distribution of the birds of the Blue Mountains region of southeastern Washington and northwestern Oregon. Walla Walla College, Pub. of the Dept. of Biol. Sci. and the Biol. Sta. No. $7: 65-107$.

Bretz, J H. 1928. The channeled scablands of eastern Washington. Geog. Rev., 18: 446-477.
Brock, S. E. 1914. Ecological relations of bird distribution. Brit. Birds, $8: 30-44$.

Daubenmire, R. F. 1942. An ecological study of the vegetation of southeastern Washington and adjacent Idaho. Ecol. Monogr., 12: 53-74.

Dumas, P. C. 1950. Habitat distribution of breeding birds in southeastern Washington. Condor, 52: 232237.

Harris, S. W. 1952. An ecological study of the waterfowl of the Potholes area, Grant County, Washington. M.S. Thesis, State College of Washington, Pullman. $187 \mathrm{pp}$.

- 1954. An ecological study of the waterfowl of the Potholes area, Grant County, Washington. Amer. Midl. Nat., 52: 403-432.

- and C. F. Yocom. 1952. Birds of the lower Grand Coulee and Potholes area, Grant County, Washington. Murrelet, 30: 18-28.

Johnsgard, P. A. 1954. Birds observed in the Potholes region during 1953-1954. Murrelet, 35: 25-31.

- - 1955a. Courtship activities of the Anatidae in eastern Washington. Condor, 57 : 19-27.

- $1955 \mathrm{~b}$. The relation of water level and vegetational change to avian populations, particularly waterfow1. M.S. Thesis, State College of Washington, Pullman. 166 pp.

Kennedy, C. C. 1914. The effects of irrigation on the bird life of the Yakima valley, Washington. Condor, $16: 250-255$.

Linsdale, J. M. 1938. Environmental responses of vertebrates in the Great Basin. Amer. Midl. Nat., 19: 1-206.

Low, J. B. 1941. Nesting of the ruddy duck in Iowa. Auk, 58 : 506-517.

Miller, A. W., and B. D. Collins. 1954. A nesting study of ducks and coots on Tule Lake and Lower Klamath National Wildlife Refuges. Calif. Fish and Game, 40 : 17-37.

U. S. Department of Commerce. 1955. Climatological data for the United States, by sections. Washington Section. Vol. 39(13).

U. S. Fish and Wildlife Service and State of Washington Department of Game. 1953. A preliminary report on the fish and wildlife resources and development plans recommended for Columbia Basin Project, Columbia River, Washington. 83 pp.

Wing, L. 1949. Breeding birds of virgin Palouse prairie. Auk, 66: 38-41.

Wolf, K. E. 1955. Some effects of fluctuating and falling water levels on waterfowl production. Jour. Wild. Mgt., 19: 13-23. 